\title{
Suppression of secondary hyperparathyroidism in uraemia: acute and chronic studies
}

\author{
N MUIRHEAD， G R D CATTO, N EDWARD，S ADAMI， R M MANNING， J L H O'RIORDAN
}

\begin{abstract}
A study was conducted evaluating the response of serum parathyroid hormone to acute hypercalcaemia and long term administration of 1,25-dihydroxyvitamin $D_{3}(1,25$ $\left.(\mathrm{OH})_{2} \mathrm{D}_{3}\right)$ in patients receiving maintenance haemodialysis. During infusion of elemental calcium $4 \mathrm{mg} / \mathrm{kg} / \mathrm{h}$ over four hours in 12 patients not receiving vitamin $D$ the concentration of serum amino terminal parathyroid hormone fell by $31-96 \%$ (mean $74 \cdot 8$ (SD 17.6)\%) while that of carboxy terminal parathyroid hormone changed little. There was a strong inverse correlation between baseline serum calcium concentration and percentage fall in amino terminal parathyroid hormone during infusion ( $r=$ $0.88 ; p<0.001)$. In seven patients who received prolonged treatment with $1,25(\mathrm{OH})_{2} \mathrm{D}_{3}$ after calcium infusion there was a positive correlation between maximum percentage fall in amino terminal parathyroid hormone during infusion and the percentage fall in amino terminal parathyroid hormone after $1,25(\mathrm{OH})_{2} \mathrm{D}_{3}$ treatment $(\mathbf{r}=\mathbf{0} \cdot 79$; p < 0.05).

The responsiveness of the parathyroid glands to changes in calcium in acute studies may be used to predict the efficacy of long term treatment with $1,25(\mathrm{OH})_{2} \mathrm{D}_{3}$. Patients in whom calcium infusion does not suppress parathyroid hormone may have true parathyroid autonomy and require early parathyroidectomy.
\end{abstract}

\section{Introduction}

It is widely held that autonomous or tertiary hyperparathyroidism often complicates chronic renal failure, particularly in patients receiving maintenance haemodialysis. ${ }^{12}$ This is based on the significant numbers of patients receiving haemodialysis who have a combination of hypercalcaemia and raised serum parathyroid hormone concentrations and are intolerant of vitamin $D .{ }^{13}$ In the past these patients have usually been subjected to total or subtotal parathyroidectomy in an effort to restore vitamin $\mathrm{D}$ responsiveness. ${ }^{1}$ It has always been difficult to predict which patients required parathyroidectomy, however, since some patients apparently fulfil accepted criteria for parathyroid "autonomy" but nevertheless respond to vitamin D. ${ }^{4}$

It would clearly be advantageous to identify patients with true autonomy (or at least a large degree of non-suppressibility) of the parathyroid glands at an early stage, since parathyroidectomy is the treatment of choice in these patients. Probably such an approach would prevent some of the problems that accompany prolonged tertiary hyperparathyroidism. Recently we have

\footnotetext{
Department of Medicine, University of Aberdeen, Foresterhill, Aberdeen AB9 2ZD

N MUIRHEAD, MB, MRCP, lecturer

G R D CATTO, MD, FRCPGLASG, senior lecturer

N EDWARD, MB, FRCPED, consultant physician

Department of Medicine, Middlesex Hospital, London

$S$ ADAMI, MD, research fellow

R M MANNING, PHD, research fellow

J L H O'RIORDAN, MD, FRCP, professor

Correspondence to: Dr G R D Catto.
}

shown that acute responsiveness of the parathyroids to changes in serum calcium concentration is maintained in renal failure and that it is the rate and direction of change in serum calcium rather than the absolute change that determines the magnitude of the response of parathyroid hormone. ${ }^{6}$ Long term suppression of serum parathyroid hormone may be produced by treatment with 1,25-dihydroxyvitamin $\mathrm{D}_{3}\left(1,25(\mathrm{OH})_{2} \mathrm{D}_{3}\right){ }^{7}{ }^{8}$ although patients may vary in how well they respond to such treatment. ${ }^{9}$ In this paper we define the relation between acute and chronic responsiveness of the parathyroids to appropriate stimuli in end stage renal failure and propose a simple method of identifying those patients in whom early surgical treatment of secondary hyperparathyroidism is advisable.

\section{Patients and methods \\ We conducted two separate studies.}

\section{ACUTE STUDIES}

Twelve patients aged 20-62 years (mean $35 \cdot 2$ (SD 13.1) years) who had been receiving haemodialysis for two to 68 months (25.8 (SD 26.9) months) and had not previously been given vitamin $D$ were infused with elemental calcium $4 \mathrm{mg} / \mathrm{kg} / \mathrm{h}$ (as $10 \%$ calcium gluconate in $5 \%$ dextrose) over four hours. All patients were studied immediately before a scheduled dialysis session, as described. ${ }^{6}$

Serum for measurement of parathyroid hormone concentration was separated within one hour of collection and stored at $-20^{\circ} \mathrm{C}$ until analysed. The parathyroid hormone assays were performed at the Middlesex Hospital, London, using two recently developed region specific homologous immunoradiometric assays. One assay ${ }^{10}$ was highly specific for the biologically active amino terminal region of human parathyroid hormone, while the other ${ }^{11}$ was specific for the immunologically active but biologically inactive carboxy terminal region of human parathyroid hormone. This distinction is of considerable importance, since high concentrations of circulating (but inactive) fragments of carboxy terminal parathyroid hormone constitute the major part of the total serum parathyroid hormone in chronic renal failure. ${ }^{12}$

\section{CHRONIC STUDIES}

Seven of the 12 patients infused with calcium were subsequently treated with $1,25(\mathrm{OH})_{2} \mathrm{D}_{3}$ in a dose of $0.25-1.0 \mu \mathrm{g}$ daily for their renal osteodystrophy. Blood samples for estimation of calcium, phosphate, albumin, and amino terminal parathyroid hormone concentrations were collected as above before dialysis at six weekly intervals during six to 24 months of treatment. Carboxy terminal parathyroid hormone was not measured routinely during long term treatment with $1,25(\mathrm{OH})_{2} \mathrm{D}_{3}$.

\section{Results}

Calcium infusions-The basal concentration of serum amino terminal parathyroid hormone was raised in 11 of the 12 patients, while that of carboxy terminal parathyroid hormone was raised in all patients. Serum calcium concentration rose during the infusion in all patients (mean maximal rise 0.81 (SD 0.21$) \mathrm{mmol} / \mathrm{l} ; 3.2(0.8) \mathrm{mg} / 100 \mathrm{ml}$ ) reaching supranormal values in 10 . Serum amino terminal parathyroid hormone fell in all patients by $31-96 \%$ (mean maximal fall 74.8 (SD 17.6)\%), while the concentration of carboxy terminal parathyroid hormone fell by $3-72 \%$ in 11 patients and rose by $32 \%$ in the remaining 
patient. A transient rise in carboxy terminal parathyroid hormone was noted during the first hour of infusion in five patients. There was a significant negative correlation between maximum percentage fall in amino terminal parathyroid hormone during the calcium infusion and initial serum calcium concentration (fig $1 ; \mathrm{r}=0.88 ; \mathrm{p}<0.001$ ) and a positive correlation between maximum percentage fall in amino terminal parathyroid hormone during infusion and percentage rise in serum calcium during infusion $(\mathrm{r}=0.58 ; \mathrm{p}<0.05)$. Maximum percentage change in carboxy terminal parathyroid hormone during infusion was also inversely correlated with initial serum calcium concentration $(\mathrm{r}=0.62 ; \mathrm{p}<0.05)$. There was no correlation between maximum percentage change in carboxy terminal parathyroid hormone and percentage change in serum calcium value $(\mathrm{r}=0.33 ; \mathrm{p}<0 \cdot 1)$.

Treatment with 1,25(OH $)_{2} D_{3}$-During treatment with vitamin $\mathrm{D}_{3}$ the serum calcium concentration rose significantly, while serum alkaline phosphatase activity and amino terminal parathyroid hormone concentration fell (table). The degree of suppression of amino terminal parathyroid hormone at the end of treatment with $1,25(\mathrm{OH})_{2} \mathrm{D}_{3}$ correlated with the maximal fall in amino terminal parathyroid hormone seen in the same patients (fig 2 ) during the calcium infusion $(r=0.79 ; \mathrm{p}<0.05)$.

\section{Discussion}

These results are clear evidence that the responsiveness of the parathyroid glands to appropriate acute and chronic stimulithat is, calcium infusion or a rise in serum calcium concentration

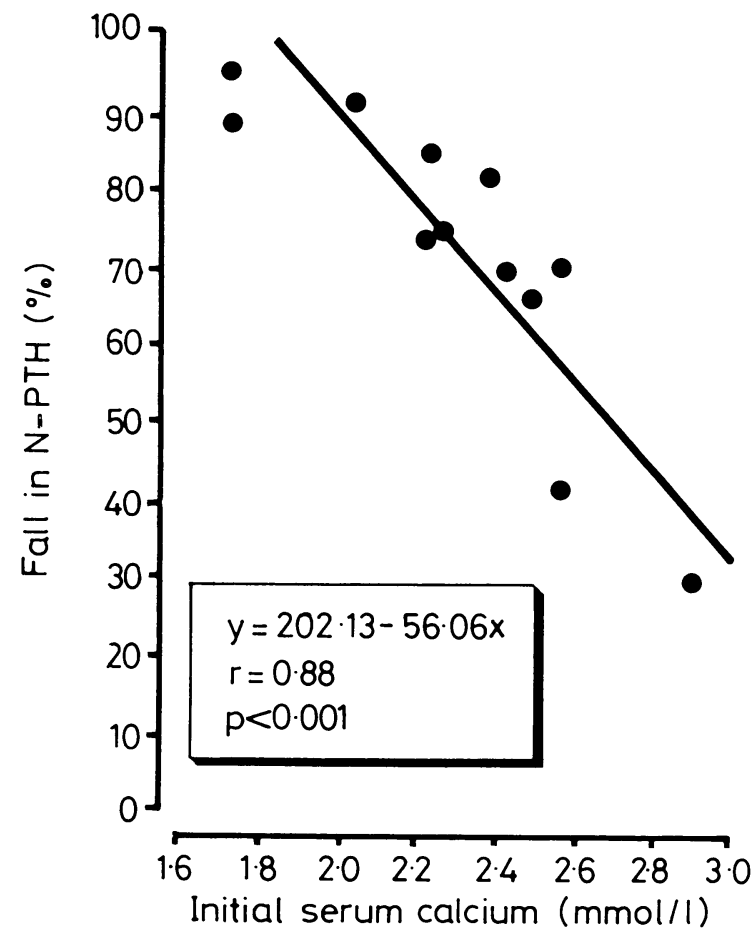

FIG 1-Relation between initial serum calcium concentrations and percentage fall in amino terminal parathyroid hormone (N-PTH) during infusion of calcium.

Conversion: SI to traditional units-Calcium: $1 \mathrm{mmol} / 1 \approx 4$ $\mathrm{mg} / 100 \mathrm{ml}$

Biochemical values during treatment with $1,25(\mathrm{OH})_{2} D_{3}$. Figures are means (SEM in parentheses)

\begin{tabular}{|c|c|c|c|}
\hline & $\begin{array}{l}\text { Serum calcium } \\
(\mathrm{mmol} / \mathrm{l})\end{array}$ & $\begin{array}{l}\text { Serum alkaline } \\
\text { phosphatase } \\
\text { (IU/1) }\end{array}$ & $\begin{array}{c}\text { Serum amino } \\
\text { terminal } \\
\text { parathyroid } \\
\text { hormone (ng/l) }\end{array}$ \\
\hline $\begin{array}{l}\text { Before treatment } \\
\text { p Value (paired } t \text { test) } \\
\text { After treatment }\end{array}$ & $\begin{array}{c}2 \cdot 19(0.35) \\
<0 \cdot 05 \\
2 \cdot 50(0 \cdot 17)\end{array}$ & $\begin{array}{c}169 \cdot 7(90 \cdot 8) \\
0 \cdot 05<\mathrm{p}<0 \cdot 1 \\
96 \cdot 0(45 \cdot 3)\end{array}$ & $\begin{array}{c}505 \cdot 1(335 \cdot 2) \\
<0 \cdot 025 \\
119 \cdot 4(152 \cdot 0)\end{array}$ \\
\hline
\end{tabular}

Conversion: SI to traditional units-Calcium: $1 \mathrm{mmol} / 1 \approx 4 \mathrm{mg} / 100 \mathrm{ml}$. induced with $1,25(\mathrm{OH})_{2} \mathrm{D}_{3}$-is retained in patients receiving maintenance haemodialysis, albeit to different degrees. There was a linear relation (fig 1) between degree of suppression of amino terminal parathyroid hormone during calcium infusion and initial serum calcium concentration, patients with higher serum calcium concentrations showing less suppression of amino terminal parathyroid hormone. This supports the concept that some degree of parathyroid autonomy may develop in patients with renal failure. Probably these patients reach a stage where the mass of parathyroid tissue present is so great that complete suppression

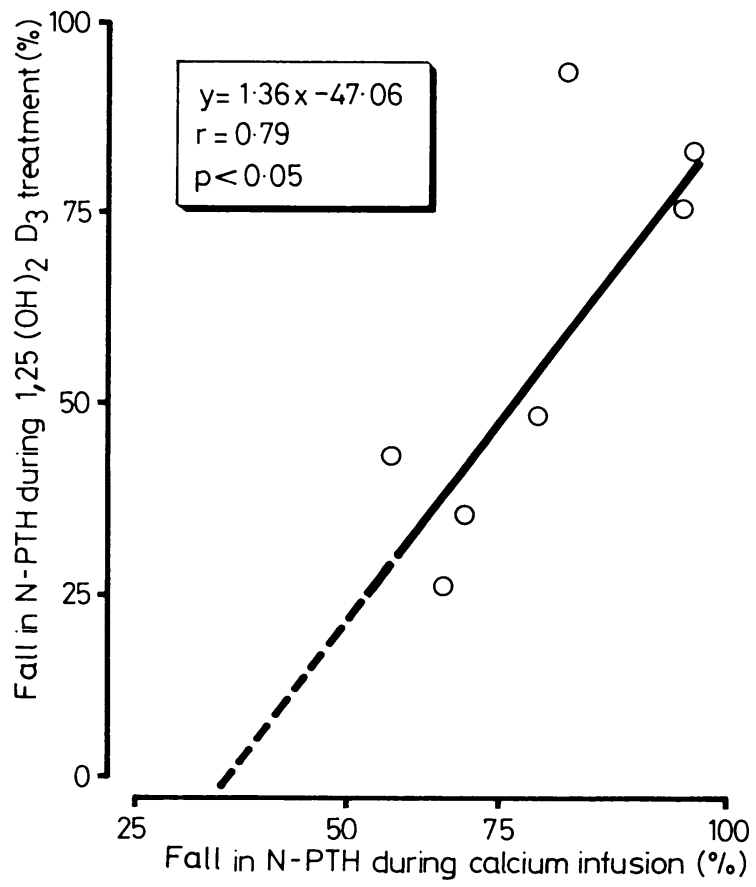

FIG 2-Relation between changes in serum concentrations of amino terminal parathyroid hormone (N-PTH) during acute calcium infusions and after long term treatment with $1,25(\mathrm{OH})_{2} \mathrm{D}_{3}$.

of output of parathyroid hormone cannot beachieved at an acceptable serum calcium concentration. Support for this hypothesis was provided by Gittes and Radde, who transplanted a large number of normal parathyroid glands into rats, which promptly developed hypercalcaemia. ${ }^{13}$ These glands were presumably responsive to normal regulatory mechanisms but still failed to suppress, suggesting that simply increasing total parathyroid mass will lead to a state of functional hyperparathyroidism that is only partly suppressible.

The response of serum carboxy terminal parathyroid hormone during calcium infusion was more variable, and the concentration rose during the first hour in five patients. There was a weak inverse correlation between percentage fall in carboxy terminal parathyroid hormone and basal serum calcium concentration. The reason for the discrepancy in the results of changes in amino and carboxy terminal parathyroid hormone during calcium infusion is complex. Fragments of carboxy terminal parathyroid hormone are cleared slowly in end stage renal failure and constitute a major portion of total parathyroid hormone measured by unselective or carboxy terminal assays. ${ }^{12}$

An assay specific for amino terminal parathyroid hormone may reflect more accurately changes in intact 1-84 parathyroid hormone concentrations and is thus more appropriate for detecting both acute and chronic alterations in biologically active concentrations of parathyroid hormone in renal failure. We conclude that the responsiveness of the parathyroid glands to acute hypercalcaemia is retained to a variable extent in end stage renal 
failure and may be assessed using an appropriate assay for parathyroid hormone. Apparently changes in amino terminal parathyroid hormone provide a more reliable and sensitive indicator of acute parathyroid suppressibility than do changes in carboxy terminal parathyroid hormone.

Identifying patients with non-suppressible parathyroid glands is of considerable clinical importance, since it is these patients who are likely to benefit most from total or subtotal parathyroidectomy. Comparing responsiveness of amino terminal parathyroid hormone to calcium infusion and percentage fall in concentration of the hormone after treatment with $1,25(\mathrm{OH})_{2} \mathrm{D}_{3}$ helps to provide an answer, since there was a significant correlation between percentage suppression of amino terminal parathyroid hormone during calcium infusion and percentage fall in amino terminal parathyroid hormone after prolonged administration of $1,25(\mathrm{OH})_{2} \mathrm{D}_{3}$. These data indicate that patients with less than $30 \%$ suppression of amino terminal parathyroid hormone during calcium infusion will fail to respond to $1,25(\mathrm{OH})_{2}$ $\mathrm{D}_{3}$. The close relation between fall in amino terminal parathyroid hormone during calcium infusion and basal serum calcium concentration suggests that it may be possible to identify those patients likely to respond to $1,25(\mathrm{OH})_{2} \mathrm{D}_{3}$ simply from their serum calcium concentrations, thus obviating the need for infusion. Nevertheless, although this may prove valid for patients with severe hypercalcaemia $(>3.0 \mathrm{mmol} / 1 ;>12.0 \mathrm{mg} / 100 \mathrm{ml}$ ), the response to calcium infusion indicates that patients with mild hypercalcaemia $(2 \cdot 6-3.0 \mathrm{mmol} / 1 ; 10 \cdot 4-12 \cdot 0 \mathrm{mg} / 100 \mathrm{ml})$ may still respond favourably to $1,25(\mathrm{OH})_{2} \mathrm{D}_{3}$. Thus preliminary infusion of calcium may be of value in predicting which patients will respond to long term treatment with $1,25(\mathrm{OH})_{2} \mathrm{D}_{3}$ and which patients would benefit most from early parathyroidectomy.

The research reported in this paper was supported by grants from the Medical Research Council and the National Kidney Research Fund.

\section{References}

1 Slatopolsky E, Rutherford WE, Hoffstein PE, Elkan IO, Butcher HR, Bricker NS. Non-suppressible secondary hyperparathyroidism in chronic progressive renal disease. Kidney Int 1972;1:38-46.

${ }^{2}$ Somerville PJ, Tiller DJ, Evans RA. What is tertiary hyperparathyroidism ? Aust NZ F Med 1975;5:551-6.

${ }^{3}$ Coburn JW, Brickman AS, Sherrard DJ, et al. Use of 1,25-(OH) vitamin $\mathrm{D}_{3}$ to separate "types" of renal osteodystrophy. Proc Eur Dial Transplant Assoc 1977;14:442-50.

${ }^{4}$ Vosik WM, Anderson CF, Steffee WP, Johnson WJ, Arnaud CD, Goldsmith RS. Successful medical management of osteitis fibrosa due to "tertiary" hyperparathyroidism. Mayo Clin Proc 1972;47:110-3.

5 Johnson WJ, Goldsmith RS, Beabout RW, Jowsey J, Kelly PJ, Arnaud $\mathrm{CD}$. Prevention and reversal of progressive secondary hyperparathyroidism in patients maintained by hemodialysis. $\mathrm{Am} \mathcal{J}$ Med 1974;56 827-32.

${ }^{6}$ Adami S, Muirhead N, Manning RM, et al. Control of secretion of parathyroid hormone in secondary hyperparathyroidism. Clin Endocrinol (Oxf) 1982;16:463-73.

${ }^{7}$ Muirhead N, Adami S, Sandler LM, et al. Long-term effects of 1,25dihydroxy vitamin $\mathrm{D}_{3}$ in renal osteodystrophy. $Q 7$ Med 1982:51:424-7.

${ }^{8}$ Goldstein DA, Malluche HH, Massry SG. Management of renal osteodystrophy with $1,25-(\mathrm{OH})_{2} \mathrm{D}_{3}$. 1. Effects of clinical, radiographic and biochemical parameters. Mineral and Electrolyte Metabolism 1979;2: 35-47.

9 Coburn JW, Birdeman AS, Sherrard DJ, et al. Clinical efficacy of 1,25 dihydroxy-vitamin $D_{3}$ in renal osteodystrophy. In: Norman AW, Schaefer K, Coburn JW, et al. Vitamin D, biochemical, chemical and clinical aspects related to calcium metabolism. Berlin: De Gruyter, 1977: 657.

${ }^{10}$ Papapoulos SE, Manning RM, Hendy GN, Lewin IG, O'Riordan JLH. Studies of circulating parathyroid hormone in man using a homologous amino-terminal specific immunoradiometric assay. Clin Endocrinol (Oxf) 1980;13:57-67.

11 Manning RM, Hendy GN, Papapoulos SE, O'Riordan JLH. Development of homologous immunological assays for human parathyroid hormone. f Endocrinol 1980;85:161-70.

${ }^{12}$ Martin K, Hruska KA, Freitag JJ, Klahr S, Slatopolsky E. The peripheral metabolism of parathyroid hormone. $N$ Engl f Med 1979;301:1092-8.

${ }^{13}$ Gittes RF, Radde I. Experimental hyperparathyroidism from multiple isologous parathyroid transplants. Endocrinology 1966;78:1015-22.

(Accepted 16 November 1983)

\title{
Diabetic ketoacidosis does not precipitate haemolysis in patients with the Mediterranean variant of glucose-6-phosphate dehydrogenase deficiency
}

\author{
ODED SHALEV, ARIE WOLLNER, JACOB MENCZEL
}

\begin{abstract}
Diabetic ketoacidosis is traditionally stated as being capable of precipitating haemolysis in patients deficient in glucose-6-phosphate dehydrogenase (G6PD). This, however, is based on only a few case reports with inadequate documentation. A study was therefore conducted to review the subject in people with the Mediterranean variant of G6PD deficiency.

Perusal of the medical records for the years 1970-82 yielded 15 patients with G6PD deficiency who had been
\end{abstract}

\footnotetext{
Department of Medicine, Hadassah University Hospital, Mount Scopus, PO Box 24035, Jerusalem 91240, Israel

ODED SHALEV; $M D$, lecturer in internal medicine

ARIE WOLLNER, MD, registrar in internal medicine

JACOB MENCZEL, MD, professor of internal medicine

Correspondence to: Dr Oded Shalev.
}

admitted to hospital for a total of 36 episodes of diabetic ketoacidosis. Ten of these episodes had been complicated by haemolytic anaemia, but in every one there was unequivocal evidence of either concurrent bacterial infection or inadvertent ingestion of drugs, either of which might induce haemolysis in G6PD deficient patients. In the remaining 26 episodes there was no evidence of developing or established haemolytic anaemia.

From these findings diabetic ketoacidosis should not be regarded as a risk factor for haemolysis in the Mediterranean variant of G6PD deficiency.

\section{Introduction}

Textbooks state that diabetic ketoacidosis may precipitate haemolysis in patients with glucose-6-phosphate dehydrogenase (G6PD) deficiency. ${ }^{1}$ This, however, is based on only a few recorded cases, in which the documentation was inadequate. 